\title{
Purification and partial characterization of thioredoxin reductase from the hepatopancreas of the mollusc Mytilus galloprovincialis Lam.
}

\author{
Esra Acar ${ }^{1}$ (1) , Gözde Hasbal² (1), Nurten Özsoy²,* \\ ${ }^{1}$ Department of Biochemistry, Faculty of Medicine, Kocaeli University, 41380, Kocaeli, Turkey \\ ${ }^{2}$ Department of Biochemistry, Faculty of Pharmacy, Istanbul University, 34116, Istanbul, Turkey
}

ORCID IDs of the authors: E.A. 0000-0002-0814-0820, G.H. 0000-0002-0216-7635, N.Ö. 0000-0002-2419-9128.

Cite this article as: Acar E, Hasbal G, Özsoy N. Purification and partial characterization of thioredoxin reductase from the hepatopancreas of the mollusc Mytilus galloprovincialis Lam. Istanbul J Pharm 48 (1): 12-17.

\begin{abstract}
Thioredoxin reductase (TrxR, EC 1.6.4.5) is a ubiquitous flavoenzyme that is present from Archaea to humans, and it is the only enzyme capable of catalyzing the reduction of thioredoxin (Trx) by nicotinamide adenine dinucleotide phosphate (NADPH). Although TrxR has been purified and characterized from different bacteria, plants, and mammalian organisms, a survey of the literature revealed no studies on the purification and characterization of TrxR from the mussel Mytilus galloprovincialis Lam. In this study, TrxR was purified to homogeneity from the hepatopancreatic tissue of M. galloprovincialis Lam. by extraction, ammonium sulfate precipitation, and DEAE-Sepharose CL-6B anion and 2',5'-ADP-agarose chromatographies, and some of its kinetic properties were examined. Molar mass determined by sodium dodecyl sulfate polyacrylamide gel electrophoresis revealed only a single protein band corresponding to a molecular weight of $35 \mathrm{kDa}$. Optimum pH and temperature were found to be 7.0 and $60^{\circ} \mathrm{C}$, respectively. $\mathrm{Km}$ and $V \max$ values for $\mathrm{NADPH}$ were found to be $85 \mu \mathrm{mol}$ and $4.82 \mu \mathrm{mol} / \mathrm{min} / \mathrm{mg}$, respectively. For 5,5]-dithiobis (2-nitrobenzoic) acid (DTNB), the $\mathrm{Km}$ and Vmax values were $193 \mu \mathrm{mol}$ and $1.32 \mu \mathrm{mol} / \mathrm{min} / \mathrm{mg}$, respectively. Increasing the knowledge on the kinetic properties of TrxR will significantly increase the prospects of enzyme application as an oxidative stress biomarker in mussels and fishes for monitoring contamination in coastal environments.
\end{abstract}

Keywords: Enzyme purification, kinetic properties, Mytilus galloprovincialis Lam., thioredoxin reductase

\section{INTRODUCTION}

Thioredoxin (Trx), nicotinamide adenine dinucleotide phosphate (NADPH) and thioredoxin reductase (TrxR) comprise a thioredoxin system which exists in nearly all living cells (Arnér and Holmgren 2006). Trx, the physiological substrate for TrxR, occurs in either an oxidized or a reduced form. Reduced Trx prevents oxidation of various proteins by donating hydrogen atoms from two of the cysteine residues at its active site. Oxidized Trx is reduced by TrxR using NADPH as an electron donor (Seo and Lee 2010).

TrxR belongs to the pyridine nucleotide-disulfide oxidoreductase family and is a dimeric flavoenzyme (Lu et al. 2009). The preliminary purification and characterization studies were performed with TrxR from archaea, bacteria and anaerobic amino-acid-utilizing bacteria (Moore et al. 1964; Williams 1995; Harms et al. 1998; Horecká et al. 1998; Seo and Lee 2010; Yang and Ma 2010), fungi, some eucaryotes including plant (Reicheld et al. 2005) and intracellular parasites (Brown et al. 1996; Coombs et al. 2004; Maggioli et al. 2004; Arias et al. 2010; Kapoor and Banyal 2011). Extensive studies have been made also upon mammalian Trx system. Mammalian TrxR was purified to homogeneity from rat liver (Larsson 1973; Luthman and Holmgren 1982; Lu et al. 2009), bovine adrenal cortex (Watabe et al. 1999) and human placenta (Gromer et al. 1998). 
Acar et al. Purification and partial characterization of thioredoxin reductase from the hepatopancreas of the mollusc Mytilus galloprovincialis Lam.

Bivalve molluscs like mussels, clams and oysters are highly nutritive commercially valuable seafood species on the worldwide basis. Populations of bivalves living in coastal areas are subject to many investigations for their possible use as enzyme resources. Many references can be found in the literature to the enzymes present in the digestive system of bivalves (Yalvaç and Kuşçu, 1993; Arısan-Ataç et al., 1994; Özsoy and Berkkan, 1997; Somar et al., 2000; Can et al. 2000; Dönmez et al. 2014). As TrxR is known to be involved in maintenance of redox homeostasis and antioxidant defense by reducing disulphide sites in oxidized proteins, it was used as a biomarker in the digestive gland of wild mussels (M. galloprovincialis) for biomonitoring the marine pollution (Sureda et al. 2011). However, no report has been found in the literature on the isolation and purification of TrxR from the mussel M. galloprovincialis. This work describes for the first time the purification and characterization of TrxR from the mussel M. galloprovincialis.

\section{MATERIAL AND METHODS}

The mussels belonging to the species Mytilus galloprovincialis Lam. were obtained from the Yenikapi seaboard on the day of experiment.

\section{Purification of thioredoxin reductase}

The purification of TrxR from hepatopancreas tissue of $M$. galloprovincialis involved four steps:

1. Isolation: $73.5 \mathrm{~g}$ hepatopancreas of freshly collected 60 mussels were homogenized in $200 \mathrm{~mL}$ of $10 \mathrm{mM}$ Tris$\mathrm{HCl}$ containing $1 \mathrm{mM}$ EDTA, pH 7.5 buffer (TE buffer) by means of a homogenizer (Art-MICCRA D-1, Heitersheim, Deutschland). The homogenate obtained was centrifuged at 13,000 rpm for $20 \mathrm{~min}$ in a refrigerated centrifuge (Heraeus-Megafuge 1.OR, Thermo Fisher Scientific, Waltham, MA, USA) and the supernatant (the crude extract) was collected.

2. Ammonium sulphate precipitation: The crude extract was precipitated by ammonium sulphate at $80 \%$ saturation and left overnight in the refrigerator. The precipitate, separated by means of centrifugation at 13,000 rpm for 20 min was dissolved in TE buffer and dialyzed against the same buffer to remove the salt. The dialyzed solution was heated at $56^{\circ} \mathrm{C}$ in a water bath for $10 \mathrm{~min}$, cooled, and after centrifugation at 13,000 rpm for 20 $\mathrm{min}$ the precipitate was discarded and the supernatant was used for further purification procedure.

3. DEAE-Sepharose Chromatography: The dialysate was applied to a column of DEAE-Sepharose CL-6B (1.5x25 $\mathrm{cm}$ ) previously equilibrated with $10 \mathrm{mM}$ TE buffer. The column was washed with approximately $150 \mathrm{~mL}$ of equilibration buffer until no protein could be detected in the effluent. The enzyme was eluted with a linear gradient of $0-0.5 \mathrm{M} \mathrm{NaCl}$ in $10 \mathrm{mM}$ TE buffer. The eluate was collected in $0.5 \mathrm{~mL}$ fractions and assayed for absorbance at $280 \mathrm{~nm}$ and for enzyme activity. The fractions showing TrxR activity were pooled and concentrated by ultrafiltration with a stirred cell (Millipore Corporation, Bedford, MA 01730 USA) equipped with a PM 10 membrane (Amicon, Inc., Beverly, Mass.) under nitrogen pressure of $20 \mathrm{lb} / \mathrm{in}^{2}$. The concentrated enzyme fractions were subsequently dialyzed against TE buffer. All operations were performed at $4^{\circ} \mathrm{C}$.

4. Affinity chromatography: The main activity peak was applied to a 2',5'-ADP-agarose column $(1 \times 10 \mathrm{~cm})$ equilibrated with $10 \mathrm{mM}$ TE buffer. The column was eluted with a gradient of 0 to $0.5 \mathrm{M} \mathrm{NaCl}$ in TE buffer. The purified enzyme solution was concentrated by ultrafiltration and dialyzed against $10 \mathrm{mM}$ TE buffer. The purified enzyme was stored at $-80^{\circ} \mathrm{C}$ until used.

\section{Determination of protein concentration}

Protein concentration was determined either by the Bradford method (1976) using bovine serum albumin (BSA) as a standard or measurement of absorbance at $280 \mathrm{~nm}$.

\section{Determination of thioredoxin reductase activity}

TrxR activity was measured by the reduction of DTNB with NADPH to 5-thio-2-nitrobenzoic acid (TNB), which produces a strong yellow color that is measured at $412 \mathrm{~nm}$ (Holmgren and Bjornstedt 1995) using Thioredoxine reductase Assay Kit (Abcam, Cambridge, MA, USA) according to the manufacturer's instructions. TrxR was determined also by the insulin-dependent reduction assay described by Arnér and Holmgren (2000). Enzyme activity was expressed as $\mu \mathrm{mol} /$ $\mathrm{min} / \mathrm{mL}$ of formation of TNB by using extinction coefficient of $6.35 \mathrm{mM}^{-1}$. One unit is defined as NADPH-dependent production of $2 \mu \mathrm{mol}$ of TNB per minute.

\section{Sodium dodecyl sulfate-polyacrylamide gel electropho- resis (SDS-PAGE)}

Sodium dodecyl sulfate-polyacrylamide gel electrophoresis (SDS-PAGE) was carried out in $12.5 \%$ polyacrylamide gel slabs at $\mathrm{pH} 8.3$ by using $1 \mathrm{M}$ Tris-glycine buffer containing $0.1 \%(\mathrm{w} / \mathrm{v})$ SDS according to Laemmli's method (1970). Subunit molar mass was analyzed under reduced conditions. The purified sample was prepared by heating a protein solution in a sample buffer (125 mM Tris-HCl, pH 6.8, 2\% SDS, $10 \%$ glycerol, $0.02 \%$ bromophenol, $5 \%$ 2-mercaptoethanol) at $100^{\circ} \mathrm{C}$ for $5 \mathrm{~min}$. A low-molecular-weight calibration mixture (Amersham Biosciences, Buckinghamshire, UK) was used as standard.

\section{Kinetic properties of thioredoxin reductase}

The relationship between the $\mathrm{pH}$ variation and TrxR activity was investigated at a pH range of $6-10$ by using $500 \mathrm{mM}$ potassium phosphate buffer containing $1 \mathrm{mM}$ EDTA. The effect of temperature on the activity of the enzyme was studied between $30^{\circ} \mathrm{C}$ and $85^{\circ} \mathrm{C}$ under assay conditions. The effect 
Table 1. Purification of thioredoxin reductase of Mytilus galloprovincialis from $\mathbf{7 3 . 5} \mathbf{g}$ of wet hepatopancreas tissue

\begin{tabular}{|c|c|c|c|c|c|c|}
\hline Purification Step & $\begin{array}{l}\text { Volume } \\
\text { (mL) }\end{array}$ & $\begin{array}{l}\text { Total } \\
\text { Protein } \\
\text { (mg) }\end{array}$ & $\begin{array}{c}\text { Total } \\
\text { Activity } \\
\text { (U)* }\end{array}$ & $\begin{array}{l}\text { Specific } \\
\text { Activity } \\
\text { (U/mg)** }\end{array}$ & $\begin{array}{c}\text { Yield } \\
(\%)\end{array}$ & $\begin{array}{l}\text { Purification } \\
\quad \text { Fold }\end{array}$ \\
\hline 1-Crude extract & 200 & 3642.4 & 112298.0 & 30.8 & 100 & - \\
\hline $2-80 \%$ ammonium sulphate fraction & 12.5 & 371.3 & 1336.3 & 3.6 & 10.2 & 0.1 \\
\hline 3-DEAE-Sepharose CL-6B (10 mM) & 10 & 10.6 & 775.4 & 73.2 & 0.3 & 2.4 \\
\hline 4-2',5'-ADP-agarose (400 mM) & 1 & 0.04 & 1189.8 & 29745.8 & 0.001 & 965.7 \\
\hline $\begin{array}{l}{ }^{*} \mu \mathrm{mol} \text { TNB/min } \\
{ }_{* *} \mu \mathrm{mol} \mathrm{TNB} / \mathrm{min} / \mathrm{mg} \text { protein }\end{array}$ & & & & & & \\
\hline
\end{tabular}

of substrate concentration on the velocity of the enzyme reaction was investigated by using varying concentrations of NADPH (0.015-0.24 mM) and DTNB (0.19-3 mM) as substrates. $\mathrm{Km}$ and Vmax were calculated by means of the equation of Lineweaver-Burk plot.

\section{RESULTS AND DISCUSSION}

The thioredoxin and glutathione systems are the two major thiol-dependent reductases that maintain a reducing intraenvironment in the presence of oxygen (Lu et al. 2009). In this study, approximately $40 \mu \mathrm{g}$ of the purified enzyme was obtained from $73.5 \mathrm{~g}$ hepatopancreas of the mollusc M. galloprovincialis. The enhanced purification was primarily due to the use of 2,5-ADP as an affinity ligand for purification of NADPH-binding proteins, a procedure previously described by Brodelius et al. (1974). The use of the affinity step resulted in a $0.001 \%$ yield of enzyme with a specific activity of 29 $745.8 \mathrm{U} / \mathrm{mg}$ protein (Table 1). Earlier purification schemes for Trx and TrxR involved anion exchange and affinity column chromatography steps. Affinity column chromatography was used as the initial purification step by Pigiet and Conley (1977), who purified both TrxR and glutathione reductase (GR) 300-fold in one step. However, it was reported that the use of affinity chromatography after several initial purification steps resulted in greater column yield. Williams et al. (1967) reported that, GR and TrxR, each purified by a two-step chromatographic procedure including anionexchange chromatography and affinity chromatography, bind to the affinity gel at the extent of 600 and 570 units/ $\mathrm{mL}$ of gel respectively; while using a crude extract, only 116 and 26 units $/ \mathrm{mL}$ gel of each enzyme bind to the affinity gel. This may be due to the presence of several NADPH-binding proteins competing with the desired proteins in the crude extract (Pigiet and Conley 1977). By a combination of anion exchange and affinity chromatography, TrxR was purified to homogeneity from Streptomyces aureofaciens 3239 (Horecká et al. 1998), a protozoan parasite Giardia duodenalis (Brown et al. 1996), and the worm Fasciola hepatica (Maggioli et al. 2004). TrxR from rat liver with specific activity of 625 $\mathrm{U} / \mathrm{mg}$ was obtained by chromatography on Sephadex and on DEAE-cellulose (Larsson 1973). The method described here for the purification of TrxR from the hepatopancreas tissue of M. galloprovincialis has resulted in a preparation with higher specific activity.

The procedure used for the purification of the TrxR from M. galloprovincialis, was similar to that used for the purification of this enzyme from anaerobic amino-acid utilizing bacteria (Eubacterium acidaminophillum, Clostridum litorale, C. sticklandii, C. sporogenes, C. cylindrosporum and Tissierella creatinophilla) as described by Harms et al. (1998). The proteins isolated in this study did not bind to DEAE-Sepharose and were eluted with the washing buffer (Figure 1). However, they were bound tightly to the affinity gel material and eluted with $0.4 \mathrm{M} \mathrm{NaCl}$ (Figure 2) as reported by Harms et al. (1998). The affinity step permitted the rapid and high yield purification of large quantities of enzyme for subsequent use in structural studies.

All described purification schemes for the TrxR involve a heat denaturation step; $65^{\circ} \mathrm{C}, 5 \mathrm{~min}$ (Moore et al. 1964) $70^{\circ} \mathrm{C}, 8 \mathrm{~min}$ (Williams et al. 1967); $60^{\circ} \mathrm{C}$ (Maggioli et al. 2004); $56^{\circ} \mathrm{C}, 10 \mathrm{~min}$ (Lu et al. 2009). In this study, heat treatment was also an important step for the enrichment of the enzyme, in which otherwise difficult-to-remove contaminating proteins were eliminated. The heat treatment was effective in simplifying the purification procedure and increasing the yield.

Optimum $\mathrm{pH}$ for TrxR have been reported to exist generally at pH 7.5 (Watabe et al. 1999), 7.4 (Kapoor and Banyal 2011), 7.7 (Williams 1995) and 6.5 (Yang and Ma 2010). Optimum $\mathrm{pH}$ values for TrxR determined in the present study was 7.0, which is within the mentioned range (Figure 3).

The optimum temperature of TrxR was found to be $60^{\circ} \mathrm{C}$ (Figure 4). However, the enzyme activity was reduced at $70^{\circ} \mathrm{C}$. Similarly, the activity of TrxR from $D$. radiophilus was drastically reduced at $80^{\circ} \mathrm{C}$ and completely inactivated at $90^{\circ} \mathrm{C}$ (Seo and Lee 2010). TrxR from the hyperthermophilic bacterium Thermotoga maritima was reported to display a relatively high thermostability (up to $95^{\circ} \mathrm{C}$ ) (Yang and Ma 2010). Thermostable enzymes have considerable potential in biotechnical applications because of their resistance to heat denaturation and consequently lower replacement costs when enzymes are integrated into high 
temperature processes. TrxR enzymes with optimum temperature as low as $-4^{\circ} \mathrm{C}$ and $0^{\circ} \mathrm{C}$ has been reported by Kapoor and Banyal (2011) and Özgençli and Çiftçi (2016), respectively. It might be the result of the necessity for these organisms to adapt itself to environmental conditions.

$\mathrm{Km}$ and Vmax values for NADPH were $85 \mu \mathrm{mol}$ and 4.8 $\mu \mathrm{mol} / \mathrm{min} / \mathrm{mg}$, respectively (Figure 5 ). Also, $\mathrm{Km}$ and $\mathrm{Vmax}$

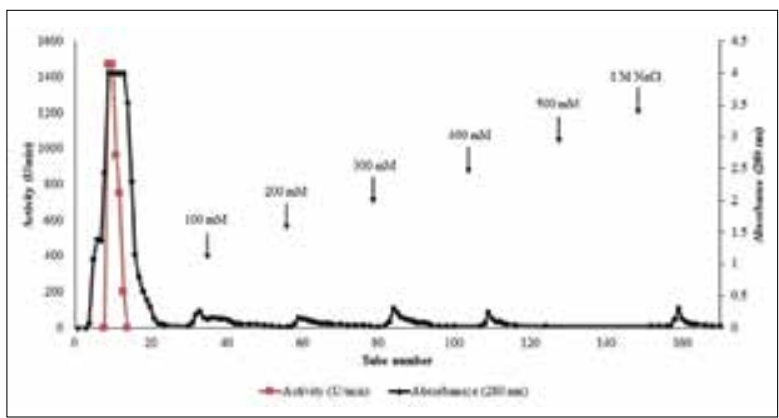

Figure 1. DEAE-Sepharose CL-6B ion exchange chromatography. Elution profile of the $80 \%$ ammonium sulphate fraction of Mytilus galloprovincialis hepatopancreas tissue crude extract.

Column: $25 \times 1.5 \mathrm{~cm}$, sample volume: $12.5 \mathrm{~mL}$ ( $371.3 \mathrm{mg}$ protein), flow rate: $48 \mathrm{~mL} /$ hour, the enzyme was eluted with a linear gradient of $0-1 \mathrm{M}$ $\mathrm{NaCl}$ in $10 \mathrm{mM}$ TE (pH 7.5) buffer.

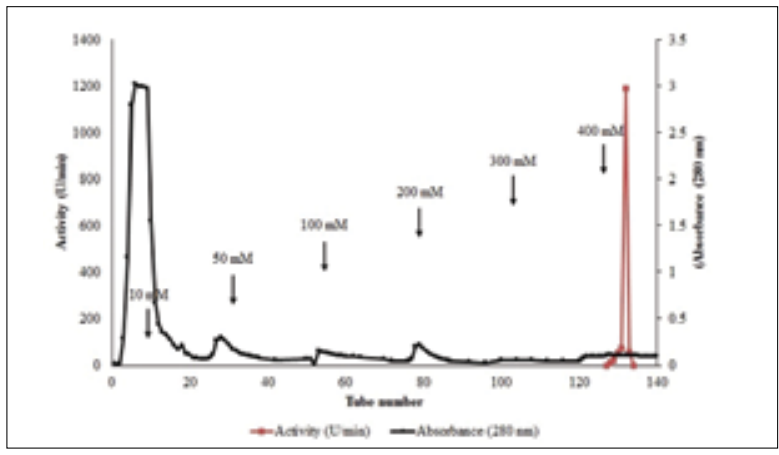

Figure 2. 2',5'-ADP-agarose chromatography of thioredoxin reductase after DEAE-Sepharose CL-6B purification.

Column: $1 \times 10 \mathrm{~cm}$, sample volume: $1 \mathrm{~mL}$ (10.6 mg protein), flow rate: 1 $\mathrm{mL} / \mathrm{min}$, the enzyme was eluted with a linear gradient of $0-0.5 \mathrm{M} \mathrm{NaCl}$ in $10 \mathrm{mM}$ TE (pH 7.5) buffer.

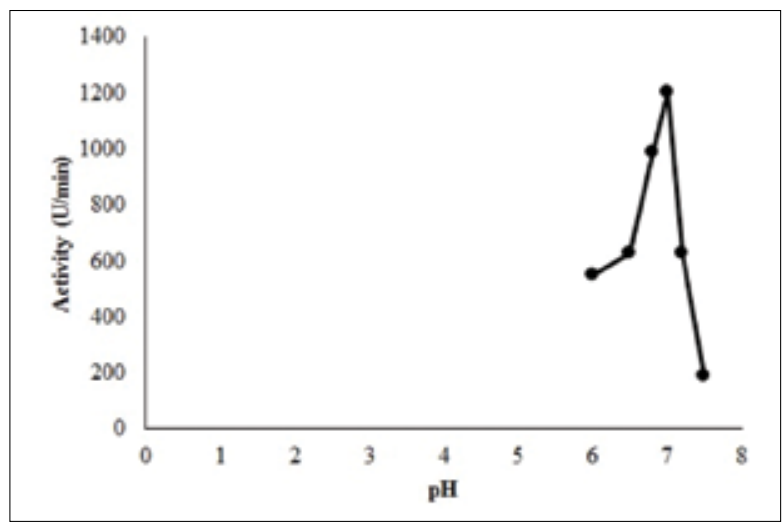

Figure 3. Effect of $\mathrm{pH}$ on Mytilus galloprovincialis hepatopancreas tissue thioredoxin reductase activity. values for DTNB were found to be $193 \mu \mathrm{mol}$ and $1.32 \mu \mathrm{mol} /$ $\mathrm{min} / \mathrm{mg}$, respectively (Figure 6). $\mathrm{Km}$ and Vmax values for DTNB were lower or comparable to that reported for Plasmodium berghei $(\mathrm{Km}=125 \mu \mathrm{mol} ; \mathrm{Vmax}=100 \mu \mathrm{mol} / \mathrm{min})(\mathrm{Ka}-$ poor and Banyal 2011). Deinococcus radiophilus ( $\mathrm{Km}=463$ $\mu \mathrm{mol} ; \mathrm{Vmax}=756 \mu \mathrm{mol} / \mathrm{min}$ ) (Seo and Lee 2010) and rat liver ( $\mathrm{Km}=660 \mu \mathrm{mol})$ (Luthman and Holmgren 1982) and higher than that reported for rainbow trout $(\mathrm{Km}=0.828$

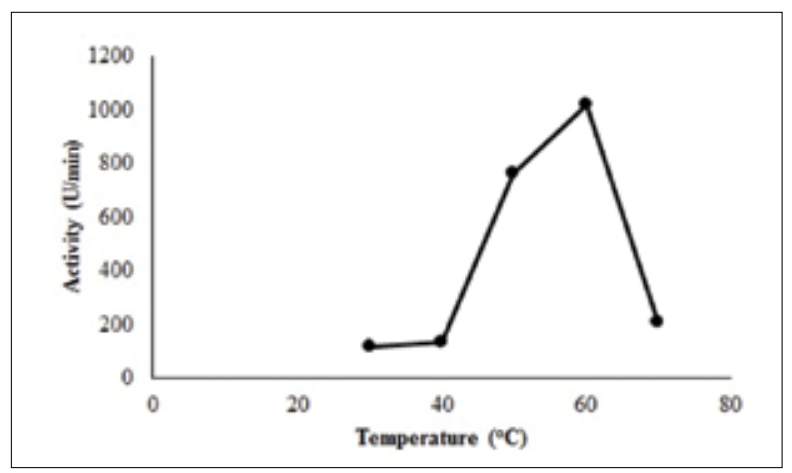

Figure 4. Effect of temperature on Mytilus galloprovincialis hepatopancreas tissue thioredoxin reductase activity.

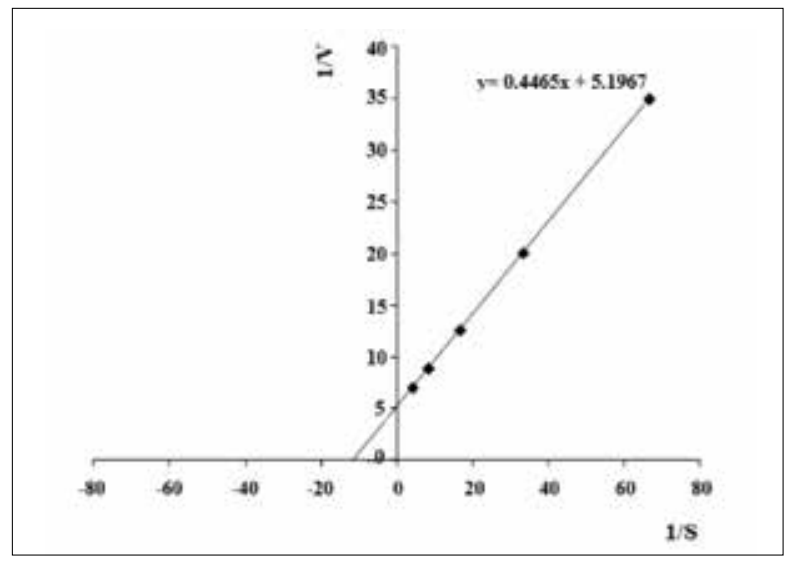

Figure 5. Effect of different concentrations of NADPH on the activity of Mytilus galloprovincialis hepatopancreas tissue thioredoxin reductase activity $(-1 / \mathrm{Km}=-11.76)$.

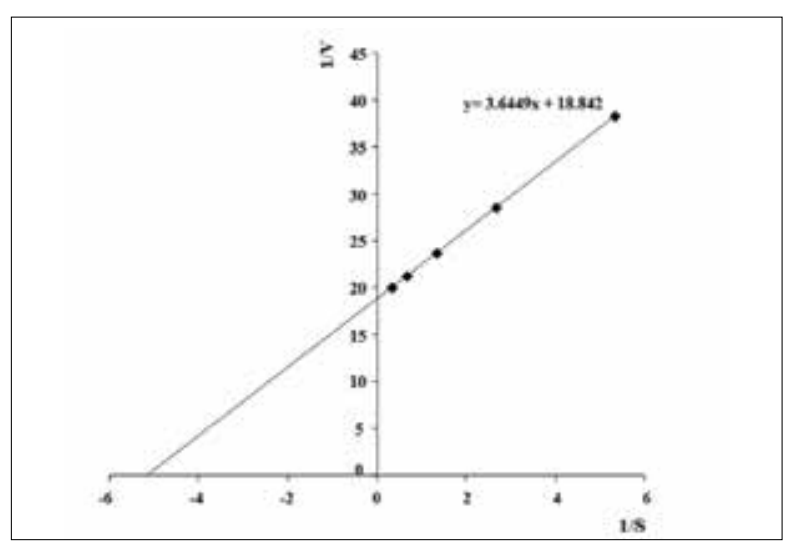

Figure 6. Effect of different concentrations of DTNB on the activity of Mytilus galloprovincialis hepatopancreas tissue thioredoxin reductase activity $(-1 / \mathrm{Km}=-5.18)$. 


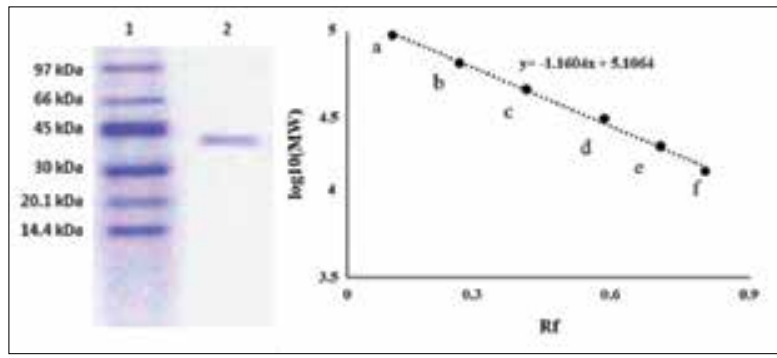

Figure 7. SDS-PAGE electrophoresis of the purified thioredoxin reductase after affinity chromatography.

Line 1: Low molecular weight proteins la: phosphorylase $97 \mathrm{kDa}, \mathrm{b}$ : albumin $66 \mathrm{kDa}$, c: ovalbumin $45 \mathrm{kDa}$, d: carbonic anhydrase $30 \mathrm{kDa}$, e: trypsin inhibitor $20 \mathrm{kDa}$ and f: $\alpha$-lactalbumin 14,4 kDa; Line 2: Purified enzyme after affinity chromatography.

$\mu \mathrm{mol}$ ) (Özgençli and Çiftçi (2016). Km and Vmax values for NADPH were higher than that reported for Deinococcus radiophilus ( $\mathrm{Km}=12.5 \mu \mathrm{mol} ; \mathrm{Vmax}=25 \mu \mathrm{mol} / \mathrm{min}$ ) (Seo and Lee 2010), rat liver ( $\mathrm{Km}=6 \mu \mathrm{mol})$ (Luthman and Holmgren 1982) and rainbow trout $(\mathrm{Km}=12.65 \mu \mathrm{mol})$ (Özgençli and Çiftçi (2016).

The purity of the enzyme was confirmed by SDS-PAGE showing a single band with a molecular mass of about 35 $\mathrm{kDa}$ (Figure 7). This value is the same with that reported for TrxR in prokaryotes, archaea and lower eukaryotes, but different from a protein in higher eukaryotes that was found have a MW of $55 \mathrm{kDa}$ (Williams et al. 2000).

\section{CONCLUSION}

The TrxR enzyme from mussel M. galloprovincialis was purified to homogeneity, and its properties were investigated. The results may contribute to a great number of studies applying oxidative biomarkers in mussels and fishes for monitoring environmental pollution.

\section{Acknowledgements}

This work, part of Esra Acar's master thesis, was supported by the Research Fund of Istanbul University: Project Number: 27103. Gozde Hasbal thanks to The Scientific and Technological Research Council of Turkey (TUBITAK) for PhD Scholarship Programme (BIDEB 2211-C).

\section{REFERENCES}

- $\quad$ Arısan-Ataç İ, Kuşçu I, Berkkan H (1994). a-D-Glucosidase activities in the mantle tissue of the mussel Mytilus galloprovincialis L. Acta Pharmaceutica Turcica 36: 53-58.

- Arnér ES, Holmgren A (2000). Measurement of thioredoxin and thioredoxin reductase. Curr Protoc Toxicol 24(7.4): 7.4.1-7.4.14.

- Arnér ESJ, Holmgren A (2006). The thioredoxin system in cancer. Semin Cancer Biol 16(6): 420-426.

- Arias DG, Regner EL, Iglesias AA, Guerrero SA (2010). Entamoeba histolytica thioredoxin reductase: molecular and functional characterization of its atypical properties. Biochim Biophys Acta 1820(12): 1859-1866.
Bradford MM (1976). A rapid and sensitive method for the quantitation of microgram quantities of protein utilizing the principle of protein-dye binding. Anal Biochem 72(1-2): 248254.

- Brodelius P, Larsson PO, Mosbach K (1974). The Synthesis of three AMP-analogues: N6-(6-aminohexy1)-adenosine 5'-monophosphate, N6-(6-aminohexyl)-adenosine 2,5'-bisphosphate, and N6-(6-aminohexyl)-adenosine 3', 5'-bisphosphate and their application as general ligands in biospecific affinity chromatography. Eur J Biochem 47(1): 81-89.

- Brown DM, Upcroft JA, Upcroft P (1996). A thioredoxin reductase-class of disulphide reductase in the protozoan parasite Giardia duodenalis. Mol Biochem Parasitol 83(2): 211-220.

- Can A, Akev N, Askhasi A (2000). Partial purification and characterization of aspartate aminotransferase from the hepatopancreas of the mussel Mytilus galloprovincialis Lam. J Fac Pharm Istanbul 33: 37-48.

- Coombs GH, Westrop GD, Suchan P, Puzova G, Hirt RP, Embley TM, Mottram JC, Müller S (2004). The amitochondriate eukaryote Trichomonas vaginalis contains a divergent thioredoxinlinked peroxiredoxin antioxidant system. J Biol Chem 279(7): 5249-5256.

- Dönmez Yurtpınar Ö, Yılmaz Özden T, Can A (2014). Partial purification and some properties of aspartate aminotransferase from the mantle tissue of Mytilus galloprovincialis Lam. J Fac Pharm Istanbul 44(1): 1-10.

- Gromer S, Arscott LD, Williams CHJr, Schirmer RH (1998). Human placenta thioredoxin reductase. J Biol Chem 273: 20096-20101.

Harms C, Meyer MA, Andreesen JR (1998). Fast purification of thioredoxin reductases and of thioredoxins with an unusual redox-active centre from anaerobic, amino-acid-utilizing bacteria. Microbiology 144(3): 793-800.

- Holmgren A, Bjorsnstedt M (1995). Thioredoxin and thioredoxin reductase. Methods Enzymol 252: 199-208.

- Horecká T, Perecko D, Kutejová E, Mikuláŝová D, Kollárová M (1998). Purification and partial characterization of thioredoxin reductase from Streptomyces aureofaciens. Biochem Mol Biol Int 46(4): 657-665.

- Kapoor G, Banyal HS (2011). Purification and characterization of Plasmodium berghei thioredoxin reductase. Asian J Anim Sci 5(2): 145-152.

- Laemmli UK (1970). Cleavage of structural proteins during the assembly of the head bacteriophage T4. Nature 227(5259): 680-685.

- Larsson A (1973). Thioredoxin reductase from rat liver. Eur J Biochem 35(2): 346-349.

- $\quad$ Lu J, Zhoong L, Lönn ME, Burk RF, Hill KE, Holmgren A (2009). Penultimate selenocysteine residue replaced by cysteine in thioredoxin reductase from selenium-deficient rat liver. FASEB J 23(8): 2394-2402.

- Luthman M, Holmgren A (1982). Rat liver thioredoxin and thioredoxin reductase: purification and characterization. Biochemistry 21(26): 6628-6633.

- Maggioli G, Piacenza L, Carambula B, Carmona C (2004). Purification, characterization, and immunolocalization of a thioredoxin reductase from adult Fasciola hepatica. J Parasitol 90(2): 205-211.

Moore EC, Reichard P, Thelander L (1964). Enzymatic synthesis of deoxyribonucleotides: V. Purification and properties of thioredoxin reductase from Escherichia coli B. J Biol Chem 239(10): 3445-3452. 
Acar et al. Purification and partial characterization of thioredoxin reductase from the hepatopancreas of the mollusc Mytilus galloprovincialis Lam.

- Özgençli İ, Çiftçi M (2016). Purification and characterization of mitochondrial thioredoxin reductase enzyme from rainbow trout (Oncorhynchus mykiss) liver and investigation of the in vitro effects of some metal ions on the enzyme. Turk J Chem 40(1): 174-183.

- Özsoy N, Berkkan H (1997). $\beta$-Glucosidase activities in the mantle tissue of the mussel Mytilus galloprovincialis L. Acta Pharmaceutica Turcica 39(3): 99-103.

- Pigiet VP, Conley RR (1977). Purification of thioredoxin, thioredoxine reductase and glutathione reductase by affinity chromatography. J Biol Chem 252(18): 6367-6372.

- $\quad$ Reichheld JP, Meyer E, Khafif M, Bonnard G, Meyer Y (2005). AtNTRB is the majör mitochondrial thioredoxin reductase in Arabidopsis thaliana. FEBS Lett 579(2): 337-342.

- Seo HJ, Lee YN (2010). Characterization of Deinococcus radiophilus thioredoxin reductase active with both $\mathrm{NADH}$ and NADPH. J Microbio/ 48(5): 637-643.

- Somar N, Özsoy N, Berkkan H (2000). b-Galactosidase activity in the mantle tissue of the mussel Mytilus galloprovincialis Lam. Acta Pharmaceutica Turcica 42(2,3): 80-84.

- Sureda A, Box A, Tejada S, Blanco A, Caixach J, Deudero S (2011). Biochemical responses of Mytilus galloprovincialis as biomarkers of acute environmental pollution caused by Don Pedro oil spill (Eivissa Island, Spain). Aquat Toxicol 101(3): 540549.

Yalvaç S, Kuşçu I (1993). $\beta$-D-Galactosidase isoenzymes of Mytilus galloprovincialis L. Acta Pharmaceutica Turcica 35: 45-50.

- Watabe S, Makino Y, Ogawa K, Hiroi T, Yamamoto Y, Takahashi SY (1999). Mitochondrial thioredoxin reductase in bovine adrenal cortex. Eur J Biochem 264(1): 74-84.

Williams CH, Zanetti G, Arscott LD, McAllister JK (1967). Lypoamide dehydrogenase, glutathione reductase, thioredoxin reductase, and thioredoxin. J Biol Chem 242(22): 5226-5231.

- Williams CH (1995). Mechanism and structure of thioredoxin reductase from Escherichia coli. FASEB J 9(13): 1267-1276.

- Williams $C H$, Arscott LD, Müller S, Lennon BW, Ludwig ML, Wang P-F, Veine DM, Becker K, Schirmer RH (2000). Thioredoxin reductase. Two modes of catalysis have evolved. Minireview. Eur J Biochem 267: 6110-6117.

- Yang X, Ma K (2010). Characterization of a thioredoxin-thioredoxin reductase system from the hyperthermophilic bacterium Thermotoga maritima. J Bacteriol 192(5): 1370-1376. 